\title{
KOMUNITAS SEBAGAI INFRASTRUKTUR PERKEMBANGAN SENI GRAFIS DI YOGYAKARTA
}

\author{
Alexander Nawangseto Mahendrapati \\ Fakultas Seni Rupa dan Desain ISI Surakarta \\ nawangseto@gmail.com
}

\section{ABSTRACT}

The research was conducted on the basis of there are at least three reasons why the first is, there has been no mapping to the printmaking community in Yogyakarta and their activity. Second, raise awareness college students to forming a community as a receptacle for learning, working, and do the movement of together in independent to develop printmaking. Third, the results of the study to determine the learning methods that continued as an effort to increasing the quality of the artworks of the students are, created the atmosphere at work, to providing the socialization about printmaking to the people. Qualitative descriptive study is used in analyzing the results of observations are done continuously thus obtaining a complete mapping concerning the phenomenon of the growth of the printmaking communities following the influence of existence of them in the development of printmaking in Yogyakarta, and positive values to be adopted or developed further as learning materials for graphic art students the Indonesia Institute of The Arts Surakarta. The result of research conducted in the form of mapping the art community graphic in yogyakarta and recommendations on one method learning with a system of the formation of groups small in the class in the process of the achievement of the creation for students, and a growing spirit to introduce printmaking to the people of Surakarta to become a branches of art popular.

Keywords: mapping , community , printmaking, popular.

\section{ABSTRAK}

Penelitian ini dilakukan atas dasar tiga alasan, yang pertama adalah, belum adanya pemetaan ke komunitas seni grafis di Yogyakarta dan aktivitas mereka. Kedua, meningkatkan kesadaran mahasiswa untuk membentuk komunitas sebagai wadah pembelajaran, bekerja, dan melakukan gerakan bersama secara mandiri untuk mengembangkan seni grafis. Ketiga, hasil penelitian untuk menentukan metode pembelajaran yang dilanjutkan sebagai upaya meningkatkan kualitas karya seni siswa, menciptakan suasana di tempat kerja, hingga memberikan sosialisasi tentang seni grafis kepada masyarakat. Penelitian deskriptif kualitatif digunakan dalam menganalisis hasil pengamatan yang dilakukan terus menerus sehingga diperoleh pemetaan yang lengkap mengenai fenomena pertumbuhan komunitas seni grafis berikut pengaruh keberadaannya dalam pengembangan seni grafis di Yogyakarta, dan nilai-nilai positif yang akan diadopsi, atau dikembangkan lebih lanjut sebagai bahan belajar bagi mahasiswa seni grafis Institut Seni Indonesia Surakarta. Hasil penelitian berupa pemetaan komunitas seni grafis di Yogyakarta dan menjadi rekomendasi pada metode pembelajaran dengan sistem pembentukan kelompok-kelompok kecil di kelas dalam proses pencapaian ciptaan siswa yang semakin berkembang. Selain itu juga untuk memperkenalkan seni grafis kepada masyarakat Surakarta untuk menjadi cabang seni yang populer.

Kata kunci: pemetaan, komunitas, seni grafis, populer

\section{PENDAHULUAN}

\section{Seni grafis secara konven-}

sional dikenal memiliki empat teknik

utama yaitu cetak tinggi (relief

print), cetak dalam (intaglio), cetak datar (planografi), dan cetak saring (serigrafi). Kemunculan seni grafis di Indonesia dimulai pada masa menjelang kemerdekaan yang dibuat dengan tujuan menyebarkan 
propaganda untuk menumbuhkan semangat dalam merebut kemerdekaan. Para perintis seni grafis adalah perupa, pelukis dan pematung, yang menemukan alternatif dalam kesenian mencetak.

Baharoedin M.S di Jakarta dan Mochtar Apin di Bandung, misalnya, yang membuat sekumpulan karya grafis untuk dikirimkan kepada negara-negara sahabat yang telah mengakui kedaulatan Indonesia pada 1946 adalah para pelukis. Mereka ditugaskan untuk mempersiapkan karya-karya grafis itu oleh "Oeroesan Pemoeda Perhoeboengan Loear Negeri" yang merupakan bagian dari Sekretariat Negara (Mulyadi, 2000: 8). Momentum inilah yang dianggap sebagai penanda lahirnya seni grafis di Indonesia. Pada masa selanjutnya di Yogyakarta muncul nama-nama seperti Suromo, Abdul Salam, dan Widayat, kemudian hadir pula nama Sun Ardi, Eka Suprihadi, dan Edi Sunaryo hingga pada generasi berikutnya muncul nama Agung Kurniawan serta Yamyuli Dwi Imam yang makin memperkuat pertumbuhan seni grafis, khususnya di Yogyakarta. Institusi pendidikan khususnya Perguruan Tinggi seni memiliki peranan yang cukup besar dalam pertumbuhan seni grafis se- bagai penyelenggara program pendidikan dan penyedia fasilitas studio/ laboratorium praktek baik dalam hal pengetahuan teoritik maupun dalam hal teknik penciptaan karya. Dalam kurun waktu antara tahun 2000 - 2010 muncul beberapa komunitas seni grafis di kota Yogyakarta. Walaupun lahir di dalam lingkup kampus Institut Seni Indonesia Yogyakarta namun komu nitas-komunitas tersebut dapat disebut mewakili komunitas seni grafis Yogyakarta, karena selain ISI Yogyakarta sebagai satu - satunya Perguruan Tinggi seni tempat lahirnya komunitas-komunitas tersebut juga tidak terdeteksi adanya komunitas seni grafis yang lahir dari perguruan tinggi lain di kota Yogyakarta.

Tujuan dari kegiatan ini adalah melakukan pemetaan dan pene -litian terhadap keberadaan komunitas seni grafis tersebut mulai dari semangat, aktifitas, karakteristik komunitas, hal-hal yang mendukung atau yang menghambat keberadaan (eksistensi) komunitas tersebut, dan pengaruhnya dalam perkembangan seni grafis di Yogyakarta. Fenomena tersebut dirasa penting untuk diteliti lebih jauh karena paling tidak ada tiga alasan. Pertama, belum pernah ada kegiatan pemetaan terhadap komunitas seni 
grafis yang muncul beserta segala aktifitasnya. Setiap pembicaraan mengenai seni grafis selalu mengarah pada diri seniman secara personal beserta capaian estetik dalam berkarya seni grafis. Adanya Trienal Seni Grafis Indonesia yang diselenggarakan oleh Bentara Budaya sebanyak 5 kali (tahun 2003, 2006, 2009, 2012, dan pada tahun 2015 menjadi kompetisi internasional) juga tidak diikuti dengan pemetaan daerah mana saja terdapat seniman atau komunitas yang aktif dalam seni grafis di Indonesia.

Kedua, bahwa sangat penting ada kesadaran bersama di kalangan mahasiswa untuk membangun komunitas di dalam kampus yang difungsikan sebagai wadah untuk belajar, berkarya, dan melakukan pergerakan bersama secara mandiri untuk "menghidupkan" seni grafis untuk disosialisasikan secara ma -sif kepada masyarakat supaya dikenal, diketahui, dan diapresiasi.

Ketiga, di Jurusan Seni Rupa Murni FSRD ISI Surakarta telah dirintis adanya peminatan mahasiswa ke dalam Minat Utama Seni Lukis, Seni Patung, dan Seni Grafis, maka penelitian ini sebagai upaya peningkatan kualitas kekaryaan ma -hasiswa, menciptakan atmosfer berkarya di studio kampus, mening- katkan pengetahuan tentang seni grafis.

\section{Kajian Literatur}

Dalam penelitian ini dilakukan studi tentang pustaka yang telah ditulis sebelumnya sebagai referensi tambahan dalam membedah permasalah yang dirumuskan dalam penelitian ini, referensi tersebut di antaranya adalah:

(1) Seni Grafis Yogyakarta Dalam Wacana Seni Kontemporer, Wiwik Sri Wulandari, ITB Jornal of Visual Art \& Design, Vol. 2 No.1, Maret 2008, h. 99-111.

Dalam tulisan ini dijelaskan mengenai dinamika kesenian yang bergerak di kota Yogyakarta juga memberi dampak positif bagi perkembangan seni grafis Yogyakarta, yaitu perluasan menuju pada polapola kerja non-kovensional dan ada kecenderungan untuk 'meruntuhkan batas-batas' pemahaman teknis konvensional. Selain hal tersebut upaya-upaya ruang alternatif (baik seniman/ pegrafis secara perorangan maupun studio komunitas) merupakan terobosan untuk menggali potensi teknik grafis alternatif, mensosialisasikan seni grafis secara lebih kepada masyarakat sebagai upaya membangun apresiasi masyarakat semakin menguat ter- 
hadap seni grafis.

\section{(2) Eksistensi Seni Grafis}

Monoprint dalam Kesenirupaan Yogyakarta, Bayu Aji Suseno, Journal Of Urban Society's Art, Vol.1 No.2, Oktober 2014, h.110-120.

Dalam tulisan ini diulas mengenai fenomena seni pada paruh tahun 2007 Indonesia kembali mengalami booming harga lukisan secara tidak wajar, melejit tinggi seperti tidak terkendali. Sampai pada gilirannya seni bukan lagi merupakan satu pencarian jati-diri, namun sebagai alternatif bentuk komoditas, bahkan investasi. Kemunculan seni grafis monoprint memang dipengaruhi oleh booming seni lukis. Pengaruh pasar yang dikuasai oleh kaum elite (kolektor) tentu menggemari dan memburu eksklusivitas demi menjaga prestise dari karya itu sendiri. Setelah booming seni rupa 2007 di kota Yogyakarta bermunculan pegrafis yang produktif dan konsisten menekuni seni grafis monoprint walaupun proses kreatif mereka dianggap sebagai penyimpangan terhadap konvensional seni grafis karena penyajiannya cenderung menyerupai lukisan, seperti tidak mencantumkan keterangan edisi cetak, teknik pewarnaan handcolouring, dan medium cetak kanvas.
(3) Komodifikasi Karya Seni Grafis Sri Maryanto, Bayu Widodo, dan Muhammad Yusuf Di Yogyakarta, Emmanuel Putro Prakoso, Te -sis Program Pascasarjana Universitas Sebelas Maret Surakarta, 20 15.

Dalam Tesis ini menjelaskan uraian bahwa komodifikasi seni grafis di Yogyakarta adalah sebuah proses perubahan nilai guna karya seni grafis konvensional menuju pada nilai tukar atas tujuan komersil. Ditandai dengan adanya perubahan fisik dari karya tersebut meliputi warna, ukuran, media, teknik, dan hilangnya identitas konvensi dalam karya seni grafis tersebut. Sedangkan perubahan non fisik me -liputi jumlah karya yang dicetak, munculnya nilai tambah ekonomi dalam karya, perubahan nilai harga karya dan kemudahan dalam memperoleh karya tersebut. Proses komodifikasi ini menujukkan adanya sistem dan runtutan yang panjang untuk menciptakan bentuk baru dari karya seni grafis sebagai upaya terobosan untuk memperkenalkan seni grafis secara lebih luas kepada masyarakat dan memperoleh apresiasi yang lebih tinggi pula.

\section{Metode Penelitian}

Penelitian ini lebih mengarah pada 
aspek pemetaan komunitas seni grafis beserta pergerakannya dalam upaya pengembangan dan sosialisasi seni grafis kepada masyarakat. Menggunakan kajian deskriptif kualitatif bertujuan untuk mengkaji gambaran lengkap secara sistematis, fakual, dan akurat mengenai pentingnya peran pergerakan komunitas dapat dipahami secara detail.

Penelitian dilaksanakan di kota Yogyakarta di mana seni rupa bergerak dan berkembang sangat dinamis, banyak karyakarya baru bermunculan, banyak kegiatan seni rupa diselenggarakan, banyak art space didirikan, begitu banyak komunitas seni tumbuh dengan pilihan konsep, ideologi, jalur kekaryaan, dan karakteristiknya. Demikian pula komunitas seni grafis banyak lahir dan diiringi dengan spirit yang kuat untuk mengembangkan teknik dalam seni grafis dan selalu ingin menciptakan karya-karya baru serta semangat melakukan eksperi mentasi dan eksplorasi dalam upaya pengembangan potensi seni gra -fis untuk lebih dapat diapresiasi oleh masyarakat secara lebih luas.

Bahan utama penelitian berasal dari partisipan yang berasal dari masing-masing komunitas seni grafis yang dibentuk pada kurun waktu tahun 2000-2010 di Yogyakarta. Data lisan sekaligus sebagai data primer didapat dengan melakukan wawancara mendalam dengan para personil dari komunitas. Data pendukung diperoleh dari dokumen-dokumen publikasi atau liputan dari lembaga lain terkait aktifitas yang dilaksanakan oleh komu nitas-komunitas tersebut.

Burham Bungin berpendapat metode observasi menjadi amat penting dalam tradisi penelitian kua -litatif. Melalui observasi itulah dikenali berbagai rupa kejadian, peristiwa, keadaan, tindakan yang mempola dari hari ke hari di tengah masyarakat (Bungin, 2005: 65). Diharapkan dari observasi secara terus menerus diperoleh sebuah pemetaan yang lengkap mengenai fenomena pertumbuhan komunitas seni grafis, pengaruh keberadaan mereka dalam perkembangan seni grafis di Yogyakarta, dan nilai-nilai positif yang dapat dikembangkan sebagai bahan pembelajaran bagi mahasiswa seni grafis di ISI Surakarta.

Analisis data dalam penelitian kualitatif ini dilakukan berbarengan dengan pengumpulan data secara terus menerus mulai dari awal hingga akhir penelitian. Mengacu pada teknik analisis data model Spradley 
(Sugiyono, 2017: 255) maka yang dilakukan adalah sebagai berikut:

1) Analisis Domain, untuk memperoleh gambaran yang umum dan menyeluruh dari komunitas-ko munitas seni grafis yang muncul dalam kurun waktu tahun 20002010 di Yogyakarta. Untuk menemukan kategorikategori dari situasi yang dihadapi/ dialami oleh masing-masing komunitas.

2) Analisis Taksonomi, dimana domain-domain yang dipilih tersebut dijabarkan lebih rinci dengan melakukan pengamatan sepanjang jangka waktu penelitian. Dibarengi dengan pengumpulan dokumentasi berupa dokumen tertulis, foto dan video, katalog, dan poster/ publikasi kegiatan komunitas - komunitas tersebut. Tujuannya untuk memperoleh gambaran lengkap mengenai aktifitas dan pergerakan yang dilakukan.

3) Analisis Komponensial, untuk mencari ciri spesifik pada setiap unsur internal dengan mengkontraskan antar elemen. Wawancara terus menerus dilakukan untuk memperoleh informasi spe sifik sebagai perbandingan antar komunitas tersebut mengenai latar belakang dibentuk, karakteris -tiknya, landasan pergerakan, ke giatan, perkembangan dan eksis -tensinya pada masa sekarang.

4) Analisis Tema Kultural, dilakukan untuk menemukan benang merah atau hubungan masingmasing objek dan disusun menjadi sebuah konstruksi tertentu yaitu peran serta komunitas-komunitas seni grafis tersebut dalam perkembangan seni grafis Yogyakarta.

\section{PEMBAHASAN}

Pada tahap penelusuran awal hasil korespondensi dengan narasumber perwakilan (mantan) mahasiswa Minat Utama Seni Grafis di Jurusan Seni Rupa Murni FSRD ISI Yogyakarta angkatan tahun 20002010 diperoleh data bahwa tidak pada semua tahun angkatan tersebut mahasiswa berhasil membentuk satu Komunitas. Informasi yang diperoleh dari hasil observasi adalah sebagai berikut:

Sebanyak 6 (enam) angkatan tidak membentuk komunitas, yaitu pada angkatan tahun 2002, 2003, 2004, 2005, 2006, dan 2008. Beberapa ada yang mendirikan komunitas namun belum sempat melakukan aktifitas bersama, ada yang sengaja membentuk komunitas yang bergerak dalam ranah seni visual yang lebih luas, dan ada yang tidak 
membentuk komunitas angkatan. Sebanyak 5 (lima) angkatan berhasil membentuk dan melakukan pergerakan secara khusus pada seni grafis ditambah satu komunitas lagi yang dibentuk secara kolektif oleh beberapa mahasiswa dari beberapa angkatan (1997-2000) dan dideklarasikan sebagai komuni -tas "di luar kampus" pada tahun 2001 dan masih aktif hingga sekarang.

Berdasarkan temuan awal tersebut penulis lebih fokus melaku -kan penelitian terhadap 6 (enam) komunitas yang berhasil dibentuk, maka pemetaan mengenai Komunitas Seni Grafis di kota Yogyakarta beserta pergerakannya adalah sebagai berikut:

\section{Tumor Ganas (Angkatan tahun 2000)}

Konsep namanya dirumuskan bersama makna dari "Tumor Ganas" adalah bahwa seperti halnya penyakit tumor meskipun seni grafis ini masih kecil tetaplah ganas dan mematikan. Secara struktural, kepengurusan terdiri dari Ketua, Sekretaris dan Bendahara, namun hirarki dalam organisasi diurai agar menjadi lebih mudah. Kegiatan "Tumor Ganas" tidak hanya dikomando oleh ketua tetapi lebih ke penunjukan siapa yang menjadi koordinator pada masingmasing project. Koordinator ini nanti yang membentuk tim kerja dan anggota lain akan turut mendukung. Sistem ini disepakati bersama sebagai jalan untuk saling belajar, saling bergantian atas jenis kerja yang berbeda, agar nantinya masing-masing dari anggota bisa merasakan bagaimana cara hidup dan menjalankan sebuah komunitas seni. Visi misi Tumor Ganas lebih pada pergerakan untuk mensosialisasikan seni grafis kepada masyarakat, baik lewat pameran atau workshop.

Kekuatan yang dimiliki oleh komunitas ada pada sikap saling berbagi ilmu antar individu, persaingan yang sehat dengan cara membentuk kelompok-kelompok ke -cil di dalam komunitas untuk berpameran, tujuannya agar masingmasing anggota termotivasi untuk berkarya seni pula. Sedangkan factor penghambat adalah bahwam "Ketua" selalu jadi kambing hitam atas kegagalan suatu proyek atau mandegnya organisasi.

Sepanjang masa aktifnya anta -ra tahun 2000 hingga tahun 2006 Tumor Ganas pernah mengadakan workshop dan pameran di Ambulu, Jember; workshop seni rupa di 
UKM Seni Rupa di Universitas Gajah Mada Yogyakarta; Ramadhan Fair with Tumor Ganas di Sasono Hinggil Keraton Kasultanan Yogyakarta; Pameran Seni Grafis di 50 titik jalan di kota Jogja; hingga Pameran CP Open Biennale. Sangat disayangkan, menurut salah satu anggota anggota Tumor Ganas menyatakan, semua arsip dan dokumen dari Tumor Ganas yang tersimpan dalam satu almari lenyap karena terbawa banjir yang pernah melanda kabupaten Sleman, tempat tinggal anggota yang menyimpan arsip-arsip tersebut. Pada masa selanjutnya komunitas ini menjadi mengambang, tidak terarah, masingmasing anggota sibuk mencapai kelulusan studinya, juga masing-masing sudah mulai memiliki pilihan dan menjalani jalur kesenimanannya sendiri. Tumor Ganas auto pilot sampai masing-masing satu persatu lulus kuliah. Sekarang keberadaan komunitas Tumor Ganas masih mengambang, tidak mau dibilang mati tetapi juga belum bergerak dan beraktifitas lagi sebagai satu komunitas.

\section{Pisangseger (Angkatan tahun 2001)}

Nama "Pisangseger" memiliki kepanjangan yaitu Pisuhan Sema- ngat Seni Grafis. Latar belakang pendirian kelompok ini untuk melanjutkan tradisi mendirikan kelompok angkatan. Pemilihan nama tersebut berdasarkan ada komentar yang mengatakan bahwa anggota kelompok ini sering mengeluarkan kata makian (Jawa: pisuhan) maka disepakati bersama menetapkan nama Pisangseger. Selanjutnya dibuatkan konsep pengartian nama tersebut yaitu bebas memaki-maki secara cerdas dengan media seni cetak grafis. Struktur organisasinya tidak terlalu hirarkis dan sistematis, semua keputusan diambil berdasar kesepakatan bersama secara musyawarah termasuk pada pembagian tugas dan kerja. Semua anggota memiliki tanggungjawab, beban, dan peran serta yang sama terutama jika sedang mengerjakan suatu proyek tertentu. Visi dan misi Pisangseger pada mulanya hanya mengerjakan tugas-tugas kuliah di studio bersama-sama. Namun pada akhirnya beraktivitas dengan semangat printmaking baru, yaitu dengan menerbitkan kompilasi karya cetak yang kemudan dijual ataupun dibagi-bagikan kepada masyarakat umum sebagai upaya untuk memperkenalkan dan mempoulerkan se -ni grafis secara luas. Semangat yang mendasari kelompok ini tetap 
solid adalah rasa kekeluargaan, dimana anggota yang beraal dari berbagai daerah saling merasakan sebagai satu keluarga yang saling loyal dan menguatkan satu sama lain. Selain itu persamaan minat dan aktifitas berkesenian dengan medium seni cetak grafis yang mejadi pengikat batin untuk selalu bertemu, berkumpul, bersama-sama berkarya dan pergerakan.

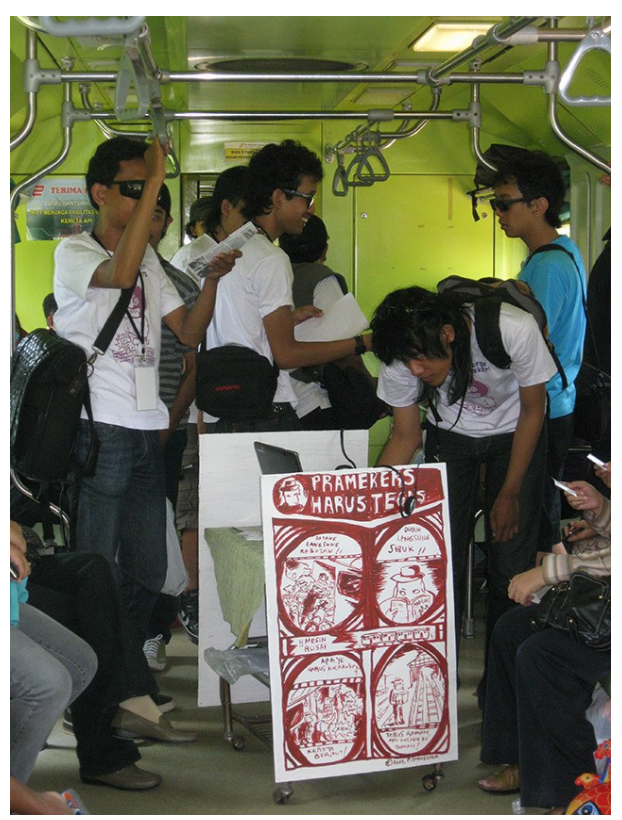

Gambar 1

"Dari Pisangseger Untuk Pramekers" Project on the Move di atas KA Pramex, Biennale Jogja X, 2009 (Dok: Pisangseger)

Faktor yang disadari sebagai kelemahan yang masih harus diperbaiki adalah dalam hal menyelaraskan ego dan idealisme tiap personil, karena pada kelanjutannya setiap anggota Pisangseger me- miliki keinginan dan tujuan yang ber -beda-beda.

\section{Tangan Reget (Angkatan tahun 2007)}

Konsep dari penamaan kelom -pok Tangan Reget adalah bahwa secara harafiah "tangan reget" (bahasa Jawa) berarti "tangan kotor" adalah hal yang tidak diperkenankan dalam praktik seni grafis, yang dituntut bersih, rapih dan sempurna dalam menghasilkan karya cetak yang layak untuk dipresentasikan. Berangkat dari situlah kelompok yang saat itu baru menekuni seni grafis ini berusaha mengesampingkan aturan-aturan atau kebiasaan, dan mengolah daya kreatifitas anggota-anggotanya secara bebas dan mandiri, sehingga bahwa tangan yang kotor dalam berkarya adalah sebuah proses dan niscaya diperlukan penghayatan, pergaulan dan improvisasi yang intensif namun selalu berusaha menyajikan karya terbaik.

Tujuan awal didirikan kelompok ini adalah untuk berkarya seni grafis bersama, sedangkan visi-misinya yaitu mewadahi proses kreatif dalam berkarya seni grafis, tempat diskusi dan berbagi mengenai pencapaian artistik dalam kekaryaan. Konsep organisasinya adalah se- 
mua personil individu adalah ketua sekaligus anggota. Kelompok ini meyakini dengan begitu setiap kepala yang ada di Tangan Reget adalah penting dan memiliki hak serta kewajiban yang sama. Aplikasinya adalah, setiap kali ada pertemuan untuk membicarakan suatu program maka bagi personil yang gagasannya diterima oleh kelompok untuk dilaksanakan, otomatis menjadi ketua pelaksana (koordinator) kegiatan tersebut. Beranggotakan 24 orang namun setelah mengalami seleksi alam sekarang tersisa 5 orang yang masih intensif melakukan komunikasi dan berkarya grafis bersama.

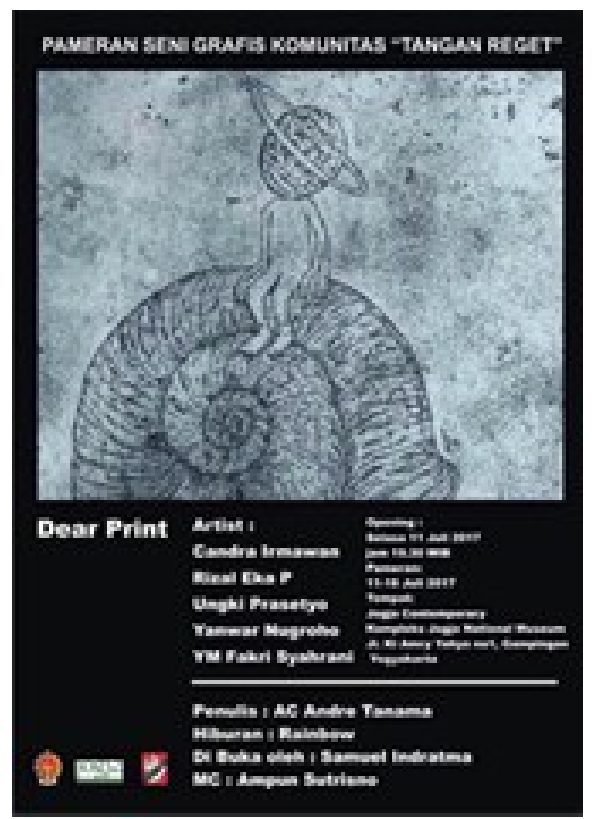

Gambar 2

Poster Pameran Seni Grafis Komunitas Tangan Reget “Dear Print" Jogja Contemporary, tahun 2017 (Dok: Tangan Reget)
Semangat yang dibangun Tangan Reget adalah bahwa semua yang dilakukan didasari untuk mempresentasikan seni grafis, dan bagi anggotanya bila berpameran tetap menggunakan atribut/ mengatasnamakan "Tangan Reget" walaupun tidak melibatkan seluruh anggota secara utuh. Hal yang menjadi kekuatan utama kelompok ini adalah kekeluargaan, sedangkan kelemahan yang terus menerus berusaha diperbaiki adalah sikap profesionalisme sebagai kelompok seni grafis harus diperkuat.

Aktifitas yang dilakukan oleh Tangan Reget di antaranya adalah: "Kupu-kupu Cukil Kayu”, di Srisasanti Gallery Yogyakarta, tahun 2007; " Seniku Tak Berhenti Lama“, di Taman Budaya Yogyakarta, tahun 2008; BIENALE JOGJA $X$ "Jogja Jamming": Instalasi" dan "Public On The Move", Alun-Alun Kidul Yogyakarta, tahun 2009; “Jogja Dunia Boneka" bersama Tangan Reget, di Taman Pintar Yogyakarta, tahun 2010; "In-Flux", di Jogja Gallery Yogyakarta, tahun 2011; FKY "Future Of Us", Gedung Bank Indonesia Yogyakarta, tahun 2012; "Bukan Musik Bukan Seni Rupa", di Gedung Ajiyasa ISI Yogyakarta, tahun 2013; Pameran "Sugeng Rawuh \#3", di Survive Garage 
Yogyakarta, tahun 2014; Pameran

"Dear Print", di Jogja Contemporary

Yogyakarta, tahun 2017.

\section{Bertulang (Angkatan tahun 2007)}

Terbentuknya komunitas ini bersamaan dengan perhelatan Seni Grafis berjudul "Hi Grapher" pada tahun 2010, dari event ini bersama beberapa mahasiswa yang lebih senior dari angkatan 2005, belajar bagaimana cara berorganisasi dan belajar menggelar suatu pameran. Nama Bertulang sendiri kami ambil dari musyawarah dengan anggota. Bertulang mempunyai berbagai mak -na positif untuk komunitas, diambil dari kata "tulang" yaitu bagian tubuh yang paling kokoh dan kuat sehingga diharapkan komunitas ini menjadi kuat dan tidak cepat bubar. Kemudian sebagai mahasiswa baru dengan latar belakang yang berbeda - beda lalu menarik satu metafora tentang "tulang" satu manusia maka "Bertulang" memiliki arti kita adalah kumpulan tulang yang saling menguatkan satu tubuh (organisasi).

Visi organisasi secara umum seperti kelompok lain berusaha supaya nama komunitas "Bertulang" dikenal oleh publik dengan berbagai aktifitas yang bersifat positif terutama dalam bidang seni grafis.
Misinya adalah untuk memperkenalkan pada khalayak umum tentang apa itu seni grafis. Kelompok ini tidak memiliki struktur organisasi, hanya ketika akan mengerjakan suatu project maka baru dibentuk struktur pelaksananya sehingga pada masing-masing kegiatan akan terjadi struktur yang berbeda-beda pula. Tujuan dibentuknya kelompok ini juga sederhana, awalnya hanya sebatas mempermudah komunikasi antar anggotanya dan berkoordinasi dalam upaya berbagi dengan orang lain tentang ilmu seni cetak grafis dengan cara beberapa workshop.

Kekuatan yang dimiliki Komunitas Bertulang terletak pada rasa kekeluargaan yang sangat erat, ditambah solidaritas antar angggota pada waktu itu yang cukup baik sehingga mempermudah melaksanakan proyek-proyek kesenian. Sedangkan faktor penghambat yang dirasakan adalah sulitnya mempertahankan keaktifan seluruh anggota yang disebabkan mungkin karena kelompok ini terbentuk dalam satu lingkup kampus, sehingga setelah selesai masa studi antar anggota menjadi sulit sekali untuk bertemu.

Beberapa kegiatan yang pernah diselenggarakan oleh Bertulang antara lain adalah: 'Hi Grapher', di Jogja National Museum, Yogya- 
karta, tahun 2010 (pameran seni grafis 5 kota: Jogja, Solo, Bali, Jakarta, Bandung); "Potret Langkah Awal", di Galery Biasa Yogyakarta, tahun 2010 (pameran perdana kelompok Bertulang); "Pasar Senen Lempuyangan", pameran 2 Kota 4 Institusi, di Tujuh Bintang Art Space Yogyakarta (Bertulang berelasi dengan kelompok seni grafis dari kampus-kampus kota lain), tahun 2012; "Why Blues", Bertulang feat. Titik Lenyap, di Jogja National Museum Yogyakarta, tahun 2012; "Kasih Sayang Itu..", Udieen Aee feat. Bertulang, Studio Bertulang Yogyakarta, tahun 2012; "LempuyanganPasar Senen", di Galery Cipta II, Taman Ismail Marzuki Jakarta, tahun 2013.

\section{PrintMaking Remedy (Angkatan tahun 2010)}

Latar belakang pemilihan nama tersebut adalah bahwa kata "Remedy" berarti "penyembuhan/ pengobatan", dimaksudkan untuk terus menerus mampu menemukan cara ungkap atau pengobatan atas berbagai kegelisahan/ persoalan/ permasalahan dalam pilihan jalan kesenian derngan menggunakan teknik "Printmaking" (seni cetak grafis) sehingga setiap anggota dalam proses berkarya selalu men- dapatkan hasil yang maksimal. Didirikan atas dorongan untuk mengikuti tradisi di kampus bahwa setiap angkatan tahun ajaran mahasiswa sadar untuk membentuk sebuah kelompok. Tujuan dibentuk kelompok ini pada awalnya adalah untuk lebih saling mengenal karakter satu personal dengan yang lainnya dalam satu angkatan, mengkoordinir kerja studio pada saat perkuliahan, menjalin ikatan dalam satu angkatan yang sama-sama belajar tentang seni grafis (terutama penggunaan material dan teknik dalam seni grafis), kemudian untuk mengadakan pameran bersama dalam satu angkatan. Semangat yang men -dasari dibentuknya PMR adalah terus menerus berkarya dan bekerja di studio dibarengi dengan upaya untuk lebih mengenalkan seni grafis kepada khalayak ramai.

PMR belum pernah menyusun struktur organisasi yang baku, dikarenakan pada awal berdiri hanya didasari semangat dalam proses berkarya dan berpameran. Dalam menjalankan aktifitasnya mengandalkan pada semangat komunal (bersama-sama) dan loyalitas (rasa memiliki dan tanggungawab) terhadap nama PMR. Namun demikian untuk menentukan arah pergerakannya PMR menetapkan visi dan 
misi organisasi sebagai berikut:

- Visi: turut serta memberi warna terhadap komunitas seni grafis di dalam maupun di luar akademis.

-Misi: membangun solidaritas dan rasa kekeluargaan sesama anggota dan komunitas antar angkatan.

Kekuatan yang dimiliki oleh kelompok PMR adalah rasa kebersamaan pada anggota-anggotanya untuk tetap menjaga komunikasi dan relationship, ditambah dengan potensi daya kreatifitas masing-masing individu yang memiliki pilihan tersendiri dalam teknik maupun gaya berkarya dan menguasai pilihan jalur keseniannya dengan sangat ahli. Namun demikian disadari pula adanya kelemahan yang dimiliki, salah satunya adalah dalam hal struktur organisasi.

Harapan kelompok seni grafis yang terdiri dari bermacam-macam karakter individu yang beragam ini dapat mengobati keinginan memvisualisasikan gagasan, pemikiran ataupun suatu ekspresi yang dimiliki lewat seni grafis. Aktifitas yang pernah dilakukan oleh PrintMaking Remedy antara lain:

"FUTURE OF US FKY XXIV", workshop cukil \& Pameran kelompok PMR feat. Saki, di Museum Bank Indonesia Yogyakarta, tahun 2012; "ARTIST PROOF", pameran Seni
Grafis, di Tembi Rumah Budaya Yogyakarta, tahun 2012; Workshop "Kampungku Mencukil", di Kampung Saki Yogyakarta, tahun 2012; “LET'S START!", Performance Art Komunitas PrintMaking Remedy, Consignment Young Talented Artists Exhibition, di Waterbank Café Yogyakarta, tahun 2013; Performance Fadeout DJ PLAY \& printmaking demo in conjuction with Pra Biennale, Waterbank Café Yogyakarta, tahun 2013; "WASH \# 8" Alfin Agnuba 'OPEN STUDIO', belakang pasar Niten Yogyakarta, tahun 2013; "JOGJA KREATIF\# 6 (Car Free Day) ", Performance Art Komunitas PrintMaking Remedy, Kampanye Pra Biennale Yogyakarta, tahun 2013; “Jogja International Mini Print Festival 2013", di sepanjang Jalan Jendral Sudirman (depan kantor Harian Tribun Jogja), Yogyakarta, tahun 2013; "BUKAN MUSIK BUKAN SENI RUPA", Pameran bersama kelompok PMR, di Gedung Ajiyasa, kampus ISI Yogyakarta, tahun 2013.

PMR berencana melakukan pendataan ulang bagi anggota yang masih tinggal di Yogyakarta karena kebanyakan anggota PMR dari luar kota (Yogyakarta-pen.) untuk nantinya mengembangkan kelompok ini menjadi lebih memiliki bentuk dan 
pergerakan yang jelas.

\section{Studio Grafis Minggiran}

Studio Grafis Minggiran, berbasis di Kota Yogyakarta, adalah kelompok seni yang didirikan sebagai tempat kerja atau studio praktek yang berfokus pada pengembangan teknik seni cetak grafis (printmaking). Studio grafis minggiran dibentuk pada tahun 2001, oleh kelompok seniman yang pada waktu itu, masih berstatus sebagai mahasiswa Seni Grafis di Fakultas Seni Rupa, Institut Seni Indonesia Yogyakarta. Deklarasinya ditandai pada tanggal 1 September 2001 dalam sebuah pameran seni grafis secara kelompok oleh beberapa mahasiswa seni grafis angkatan 1997 yang menjadi pendiri awal (founders) dengan judul "CeritaCerita" di Galeri Gelaran Budaya, Yogyakarta.

Pada awalnya Grafis Minggiran masih berupa kelompok kolektif (komunitas) yang melakukan aktifitasnya baru sebatas pada pameran dan workshop bersama, kemudian timbul gagasan untuk mengkembangkan diri menjadi sebuah lembaga mandiri yang lebih progresif dan bekerja bersama dalam upaya pengembangan baik dalam hal teknik seni grafis maupun be- rupa produksi seni lainnya dengan orientasi kegiatan berupa: Open stu -dio, Workshop seni grafis, Reproduksi karya seni grafis, Tinjauan karya seni (apresiasi), Rancang Grafis, Komik studio, Mural (Wall painting), dan Art on T-shirt. Pada perkembangan selanjutnya Studio Grafis Minggiran lebih fokus menjadi ruang kerja kreatif yang dapat diakses oleh publik umum (open studio) dan memfasilitasi orang yang tertarik pada wacana mengenai atau praktek cetak grafis di Indonesia baik melalui program kursus singkat (short course) atau residensi.

Studio Grafis Minggiran melakukan beragam kegiatan pameran dan workshop seni grafis seperti pameran program apresiasi karya, proyek-proyek khusus dan workshop pada lingkup yang lebih luas untuk menyebarluaskan teknik seni grafis kepada siswa mulai Sekolah Dasar hingga Perguruan Tinggi, termasuk seniman, dan masyarakat umum. Studio Grafis Minggiran juga berupaya menjadi pusat informasi dan dokumentasi mengenai perkembangan seni cetak grafis di Indonesia, selalu berusaha untuk mejalin kerjasama dan membangun jaringan dengan lembaga dan seni kelompok masyarakat yang ada di 
Indonesia maupun luar negeri.

Berbagai aktifitas yang telah dilaksanakan oleh Studio Grafis Minggiran antara lain adalah: Pameran "Cerita - Cerita", Printmaking Exhibition, di Gelaran Budaya, Yogyakarta, tahun 2001; "Open Stock" Room Showcase by Studio Grafis Minggiran, di Kedai Kebun Resto, Yogyakarta, tahun 2004; "OPEN STUDIO", Grafis Minggiran Exhibition and Workshop, di Cemeti Art House/Via-Via Café, Yogyakarta, tahun 2006; "Jogja Printmaking Network", Exhibition and Workshop, di Taman Budaya Yogyakarta, tahun 2007; "Aku Lirik" pameran Studio Grafis Minggiran vs Kornchonk Chaos, di Galeri LIP, Yogyakarta, tahun 2008; "Ooh Messias" Printmaking Exhibition, di Bentara Budaya Yogyakarta, tahun 2008; Project On The Move 'Biennale Jogja', di Kampung Gampingan dan Taman Budaya Yogyakarta, tahun 2009; "Sin City (Earth Project)", at Indonesian National Gallery, Jakar ta, tahun 2010; "Here And There, Now And Then (HATNAT)", Print making Project, di Langgeng Art Foundation Yogyakarta, tahun 2012; "Print Parade \#01", di Studio Grafis Minggiran, Yogyakarta, tahun 2013; "Yogya Open Studio", Antena Project, Yogyakarta, tahun 2014;
"Print Parade \#02", di Studio Grafis Minggiran, Yogyakarta, tahun 2016; "Art Exhibition : Art by Arnoldii Arts Club", Featuring prints by Grafis Minggiran, Symphony II \& III, Level 2, Rendezvous Hotel, Singapore, ta -hun 2016; "A Gilman Affair", showcase of selected prints by Grafis Minggiran, Block 7, Art Day Out! at Gillman Barracks, Singapore, tahun 2016; "Collective Society", BEKRAF SPACE, Art Stage 2016, Sheraton Grand, Jakarta, tahun 2016; "Peek x Grafis Minggiran", Intaglio Exhibition, Dong Po Colonial Cafe, Singapore, tahun 2017; "Pekan Seni Grafis Yogyakarta 2017", Jogja National Museum, Yogyakarta, tahun 2017.

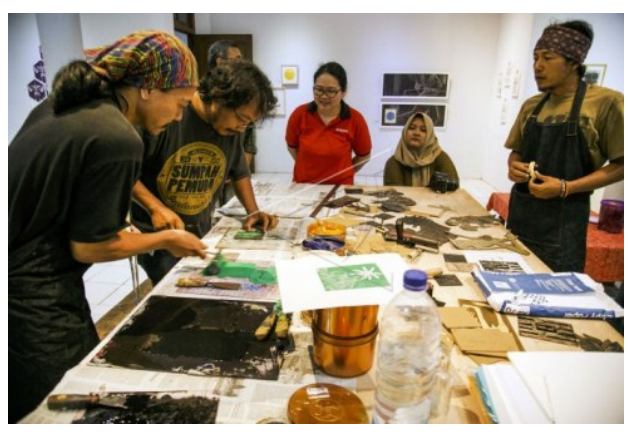

Gambar 3

Pelatihan seni grafis dengan metode cukil di Studio Minggiran (Doc: studio grafis minggiran)

\section{SIMPULAN}

Dari penelitian yang dilakukan diperoleh hasil bahwa semua komunitas yang didirikan pada kurun wak 
-tu tahun 2000-2010 tersebut memiliki tujuan yang sama dalam pergerakannya yaitu untuk memperkenalkan pengetahuan dan karya seni cetak grafis kepada masyarakat secara lebih luas untuk mendapatkan apresiasi yang lebih baik pula.

Faktor yang dianggap sebagai kekuatan utama adalah rasa kekeluargaan, kebersamaan, solidaritas, dan kecintaan terhadap seni cetak grafis. Sedangkan yang menjadi faktor penghambat adalah karena tidak disusun struktur yang jelas, tanpa program yang terarah (lebih mengandalkan ide spontan), sikap profesionalisme anggota terkait kurangnya rasa tanggungjawab untuk mengelola keberlangsungan komunitas. Terkecuali untuk Studio grafis Minggiran yang memang dibentuk dengan struktur kepengurusan yang jelas dan semakin lama berkembang dengan program-program yang terencana baik dalam hal aktifitas yang bersifat edukasi dan sebagai laboratorium pengembangan seni cetak grafis, maupun dalam usaha yang sifatnya komersial sebagai upaya pemenuhan kebutuhan finansial dalam menjalankan aktifitas komunitas maupun studio. Keberadaan komunitas-komunitas tersebut sangat berpengaruh sebagai salah satu infrastrukur dalam perkembangan seni grafis di kota Yogyakarta. Berbagai aktifitas yang dilakukan oleh komunitas-komunitas tersebut secara terus menerus dengan pameran, workshop, kampanye membuahkan hasil bahwa masyarakat dari berbagai kalangan telah mengenal karakteristik seni cetak grafis yang beragam dan unik, banyak kalangan yang berminat untuk mempelajari seni grafis, dan semakin banyak pula pecinta seni yang mengkoleksi karya-karya seni grafis.

Seni grafis di kota Surakarta baru dikenal pada kalangan yang berasal dari institusi pendidikan seni, maka berbicara mengenai seni grafis harus pula membicarakan institusi seni sebagai penyelenggara pembelajaran dan penyedia fasilitas sarana dan prasarana yang tepat bagi mahasiswa dalam menjelajahi pencapaian karakteristik visual karya seni grafis. Semangat berkomunitas perlu dibangun dan peran pentingnya membentuk komunitas perlu ditanamkan bagi mahasiswa minat utama seni grafis FSRD ISI Surakarta sejak awal menjalani masa studi. Suatu komunitas sangat penting dibentuk sebagai wadah untuk belajar, berkarya bersama, dan berkompetisi 
secara positif meningkatkan kualitas diri sekaligus juga belajar menjalankan organisasi. Berlatih menyelenggarakan suatu kegiatan bersama seperti pameran, workshop, dan lain-lain dan mengatur diri sendiri untuk memiliki satu perencanaan dan penjadwalan supaya terlatih menjadi disiplin. Namun yang lebih penting lagi adalah memupuk rasa kecintaan mahasiswa tehadap seni grafis, memberi pemahaman akan manfaat menjalani aktifitas bersama komunitas, memberi wawasan terhadap pilihan terhadap masa depan, dan mendorong pergerakan mahasiswa dalam mempopulerkan seni grafis kepada masyarakat kota Surakarta dengan cara yang menyenangkan.

\section{DAFTAR PUSTAKA}

Bungin, Burhan. 2005. Analisis Data Penelitian Kualitatif, Pemahaman Filosofis dan Metodologis ke Arah Penguasan Model Aplikasi (edisi 3). Raja Grafindo Persada,. Jakarta.

Mulyadi, F.X, dkk. 2000. Utang Kepada Apin, Baharoeddin, dan Soeromo, Katalog Setengah Abad Seni Grafis Indonesia. Kepustakaan Populer Gramedia. Jakarta.

Sugiyono. 2017. METODE PENE LITIAN Kuantitatif, Kualitatif, dan R \& D (Cet. Ke- 25). C.V ALFABETA.
Bandung.

Wiwik Sri Wulandari, Seni Grafis Yogyakarta Dalam Wacana Seni Kontemporer, ITB Jornal of Visual Art \& Design, Vol. 2 No.1, Maret 2008, h. 99-111.

Bayu Aji Suseno, Eksistensi Seni Grafis Monoprint dalam Keseni rupaan Yogyakarta, Journal Of Urban Society's Art, Vol.1 No.2, Oktober 2014, h.110-120.

Emmanuel Putro Prakoso, Komodifikasi Karya Seni Grafis Sri Maryanto, Bayu Widodo, dan Muhammad Yusuf Di Yogyakarta, Tesis Program Pascasarjana Univer sitas Sebelas Maret Surakarta, 2015 